\title{
Irrigation Frequency during Container Production Alters Rhododendron Growth, Nutrient Uptake, and Flowering after Transplanting into a Landscape
}

\author{
Carolyn F. Scagel ${ }^{1}$ \\ U.S. Department of Agriculture, Agricultural Research Service, Horticultural \\ Crops Research Unit, 3420 NW Orchard Avenue, Corvallis, OR 97330
}

Guihong Bi

Department of Plant and Soil Sciences, Mississippi State University, Mississippi State, MS 39762

David R. Bryla

U.S. Department of Agriculture, Agricultural Research Service, Horticultural Crops Research Unit, 3420 NW Orchard Avenue, Corvallis, OR 97330

Leslie H. Fuchigami and Richard P. Regan

Department of Horticulture, Oregon State University, Corvallis, OR 97330

Additional index words. landscape performance, nursery production, nutrient uptake, water use

Abstract. One deciduous cultivar of Rhododendron L., Gibraltar (AZ), and two evergreen cultivars, P.J.M. Compact (PJM) and English Roseum (ER), were grown in containers for 1 year to determine the effects of irrigation frequency during container production on plant performance the next spring when the plants were transplanted into the landscape. While in the containers, each cultivar was irrigated once or twice daily, using the same amount of water per day, and fertilized with complete nutrient solutions containing 0,35 , 70 , or $140 \mathrm{mg} \cdot \mathrm{L}^{-1}$ nitrogen $(\mathrm{N})$. Three months after transplanting into the landscape, nutrient uptake, growth, and flowering were evaluated. In general, the effects of irrigation frequency in containers on performance in the landscape differed between the deciduous cultivar and the evergreen cultivars. In AZ, less frequent irrigation in containers had a pre-conditioning effect that resulted in greater vegetative growth in the landscape but less reproductive growth. In contrast, less frequent irrigation reduced vegetative growth of evergreen cultivars in the landscape and improved flowering. Different growth responses to irrigation frequency between deciduous and evergreen cultivars appeared to be related to differences in timing of nutrient uptake and mobilization. In the deciduous cultivar, less frequent irrigation increased nutrient reserves and improved the ability of the plants to absorb and use nutrients after transplanting, but in the evergreen cultivars, it generally decreased nutrient uptake after transplanting. Less frequent irrigation also altered plant attributes that are important to consumers, including developing a sparser canopy in ER and a fuller canopy in PJM, and producing more but smaller inflorescences in both cultivars. Landscape performance was related to plant nutrition in containers; however, irrigation frequency in containers disrupted relationships between nutrition and performance in all three cultivars. Our results indicate that irrigation frequency during container production of Rhododendron results in a tradeoff between vegetative and reproductive growth the next spring when the plants are in the landscape.

Nursery practices for container-grown perennial plants attempt to optimize plant growth and appearance both in the containers and after transplanting in the landscape. Numerous factors influence plant performance after transplanting, including water and nutrient management in the nursery (Arreola et al., 2006; Cabrera and Devereaux, 1999; Cameron et al., 2008; Close et al., 2004; Franco et al., 2006; Sánchez-Blanco et al., 2004). Maintaining available water near $100 \%$ container capacity in the growing substrate may optimize plant growth (Beeson, 1992; Fare et al., 1994; Keever and Cobb, 1985; Scagel et al., 2011) but is impracticable in commercial systems (Beeson, 2006) and often leads to inefficient water use and increased nutrient leaching and runoff (Bilderback, 2002). Frequent irrigation can increase nutrient availability and uptake efficiency in containers and reduce the amount of fertilizer required for optimal growth (Raviv et al., 1999; Scagel et al., 2012).
Irrigation practices that purposefully result in plant water stress can enhance nursery crop quality by creating plants that are smaller and more able to withstand stressful growing conditions such as those in retail outlets and landscapes, a practice referred to as pre-conditioning (Cameron et al., 2006, 2008). Deficit irrigation regimes where the substrate was allowed to dry to $40 \%$ to $75 \%$ of container capacity between irrigation events can produce plants with acceptable growth (Beeson, 2006; Koniarski and Matysiak, 2013; Welsh and Zajicek, 1993). However, water limitations during container production may negatively influence nutrient reserves in the plants, which are essential for subsequent plant performance in the landscape (Cabrera and Devereaux, 1999; Scagel et al., 2011, 2012).

A combination of reduced irrigation volume and increased irrigation frequency can decrease nutrient and water runoff (Fare et al., 1994). Watering more frequently can also reduce plant water stress when the plants are well fertilized or nutrient deficient (Bi et al., 2007b; Scagel et al., 2007). For example, both high $\mathrm{N}$ status and $\mathrm{N}$ deficiency increased apparent water stress in containergrown Rhododendron (Scagel et al., 2011) and altering irrigation frequency changed the ability of Rhododendron to absorb nutrients (Scagel et al., 2011, 2012). The effects of irrigation frequency on nutrient uptake in containers therefore have the potential to alter plant performance in the landscape.

Knowledge of the potential for irrigation management practices to pre-condition plants in the nursery for future performance is important for managing end-product quality. Nursery plants with a greater ability to function in adverse conditions will have a greater chance of survival and growth after transplanting (Franco et al., 2006; Sánchez-Blanco et al., 2004). Improved irrigation control and monitoring strategies for nursery crops will increase the efficiency of water use in production settings (Lea-Cox et al., 2013). However, more information on how changes in irrigation alter end-product qualities of container-grown nursery plants is needed to implement effective water management. The objective of this study was to determine the effects of irrigation frequency during container production on spring growth, flowering, and nutrient uptake in deciduous and evergreen cultivars of Rhododendron after the plants were transplanted into a landscape.

\section{Materials and Methods}

Two evergreen cultivars of Rhododendron, PJM and ER, and one deciduous cultivar, AZ, were obtained from a commercial nursery as 1-year-old liner stock of clonally propagated plants $(\approx 7 \mathrm{~cm} \times 7-\mathrm{cm}$ cell size). Plants were transplanted on $25 \mathrm{Apr}$. 2005 into 3.8-L (\#1) containers filled with a substrate of bark, sphagnum peatmoss, perlite, vermiculite, dolomitic lime, and gypsum (SB-300; Sun Gro Horticulture, Bellevue, WA) and were grown outdoors in Corvallis, 
OR (lat. $45^{\circ} 59^{\prime} 04^{\prime \prime} \mathrm{N}$, long. $123^{\circ} 27^{\prime} 22^{\prime \prime} \mathrm{W}$ ). Information on nutrient uptake, stomatal conductance, growth, and biomass allocation while the plants were in the containers during the first year (2005) is available in Scagel et al. $(2011,2012)$.

2005 container production. Plants were fertilized twice a week from 29 Apr. to 2 Sept. 2005 with nutrient solutions containing $250 \mathrm{~mL}$ of $\mathrm{N}$-free fertilizer $\left(1.06 \mathrm{mg} \cdot \mathrm{mL}^{-1}\right.$, Cornell No N Eq. 0-6-27; Greencare Fertilizers, Kankakee, IL) or the N-free fertilizer plus 35,70 , or $140 \mathrm{mg} \cdot \mathrm{L}^{-1} \mathrm{~N}$ from $\mathrm{NH}_{4} \mathrm{NO}_{3}$. Drip irrigation was applied daily from 2 May to 30 Sept. 2005. Each treatment was either 1) irrigated to $100 \%$ container capacity (based on weekly measurements of plants fertilized with $\left.70 \mathrm{mg} \cdot \mathrm{L}^{-1} \mathrm{~N}\right)$ at $0800 \mathrm{HR}(\mathrm{W} 100)$; or 2) irrigated with the same amount of water each day as plants in the W100 treatment but in two equal-volume applications at $0800 \mathrm{HR}$ and $1430 \mathrm{HR}$ (W50). Each treatment was replicated 10 times for a total of 240 plants (three cultivars $\times$ four $\mathrm{N}$ rates $\times$ two 2 irrigation frequencies $\times 10$ replicates).

2006 landscape site. In Mar. 2006, plants were removed from the containers and transplanted $0.90 \mathrm{~m}$ apart in an untilled landscape site with a sandy loam soil (Willamette Silt Loam; fine-silty, mixed, superactive mesic Pachic Ultic Argixerolls). Based on a composite of five random samples collected to a 12-cm depth, the soil had a $\mathrm{pH}$ of 6.3 , a cation exchange capacity of $20 \mathrm{meq} / 100 \mathrm{~g}$, and contained $\approx 4 \mathrm{mg} \cdot \mathrm{kg}^{-1} \mathrm{NH}_{4}-\mathrm{N}, 2 \mathrm{mg} \cdot \mathrm{kg}^{-1}$ $\mathrm{NO}_{3}-\mathrm{N}, 11 \mathrm{mg} \cdot \mathrm{kg}^{-1}$ phosphorus (P), 200 $\mathrm{mg} \cdot \mathrm{kg}^{-1}$ potassium $(\mathrm{K}), 550 \mathrm{mg} \cdot \mathrm{kg}^{-1}$ calcium (Ca), $75 \mathrm{mg} \cdot \mathrm{kg}^{-1}$ magnesium (Mg), $60 \mathrm{mg} \cdot \mathrm{kg}^{-1}$ iron $(\mathrm{Fe}), 13 \mathrm{mg} \cdot \mathrm{kg}^{-1}$ manganese $(\mathrm{Mn}), 0.50$ $\mathrm{mg} \cdot \mathrm{kg}^{-1}$ boron (B), $0.75 \mathrm{mg} \cdot \mathrm{kg}^{-1}$ zinc ( $\mathrm{Zn}$ ), and $0.9 \mathrm{mg} \cdot \mathrm{kg}^{-1}$ copper $(\mathrm{Cu})$ (Central Analytical Laboratory, Oregon State University, Corvallis, OR). The soil surface was mulched with $6 \mathrm{~cm}$ of partially decomposed Douglas fir [Pseudotsuga menziesii (Mirb.) Franco] bark chips. After transplanting, plants were not irrigated or fertilized. The site was in partial shade after $\approx 1300 \mathrm{HR}$.

Measurements. Flowering data, recorded daily from 1 Mar. to 1 June 2006, included time of flowering (date when the first flower was fully expanded) and the total number

Received for publication 31 Mar. 2014. Accepted for publication 8 May 2014.

This work was funded, in part, by the USDA-ARS-Northwest Center for Nursery Crop Research, the Oregon State University Agricultural Research Foundation, and the American Rhododendron Society.

We gratefully acknowledge Jesse Mitchell, Suean Ott, Lisa Tribbet, and Rose Jepson for technical assistance and Monrovia Nursery, Dayton, OR, for plant materials.

Mention of trade names or commercial products in this publication is solely for the purpose of providing specific information and does not imply recommendation or endorsement by the U.S. Department of Agriculture.

${ }^{1}$ To whom reprint requests should be addressed; e-mail Carolyn.Scagel@ars.usda.gov. of flowers and inflorescences produced by 1 June 2006. Plants were harvested destructively on 19 June 2006. Shoots were cut at the soil surface, separated into leaves and stems, and divided into 1-, 2-, and 3-year-old structures. Root systems were excavated using shovels to remove a $45 \mathrm{~cm} \times 45-\mathrm{cm}$ area around each plant to a depth of $30 \mathrm{~cm}$ (soil and mulch). Roots were washed from the excavated soil and mulch over a 50-mesh screen. After 3 months in the landscape, vegetative buds in each cultivar had opened, and leaves had emerged, but very few roots extended beyond the root ball. At harvest, all of the leaves in evergreen cultivars appeared to be fully expanded, and most leaves in AZ were fully expanded except $\approx 7 \%$ of the leaves on the shoot apexes. Container-grown $\mathrm{AZ}$ can produce new leaves into August ( $\mathrm{Bi}$ et al., 2007b; Scagel et al., 2007). Leaves, stems, and roots were dried at $65{ }^{\circ} \mathrm{C}$ in a forced-air oven (Model 1380FM; Sheldon Manufacturing, Cornelius, OR), weighed, ground to pass through a 40-mesh screen using a Wiley mill (Thomas Scientific, Swedesboro, $\mathrm{NJ}$ ), and stored in airtight containers until analyzed for nutrients.

Nutrient analyses. Dried plant samples were analyzed for carbon and $\mathrm{N}$ using a combustion analyzer (TruSpec CN; Leco Corp., St. Joseph, MI) (Bi et al., 2007a) and for other macro- and micronutrients using an inductively coupled plasma-optical emission spectrophotometer (Optima 3000DV; Perkin Elmer, Wellesley, MA) after dried samples were digested in nitric acid (Scagel et al., 2008). Reference standard apple leaves (\#151, National Institute of Standards and Technology) were analyzed with experimental samples for all procedures.

Calculations. Total plant biomass was calculated as the sum of dry weights of all structures (e.g., roots, stems, and leaves). Biomass allocation was calculated as the percentage of total plant biomass in each plant structure. Biomass allocation to new structures (stems and leaves only) was calculated as the percentage of total structure biomass in the structures produced in 2006 . Net total biomass and nutrient accumulation were estimated by subtracting the average biomass or nutrient content of liners received in May 2005 (Scagel et al., 2011, 2012) from the biomass or nutrient content of individual plants harvested from the landscape in June 2006. Net 2006 growth and nutrient uptake were estimated by subtracting the average biomass or nutrient content of each cultivar and treatment combination in Nov. 2005 (Scagel et al., 2011, 2012) from the biomass or nutrient content of individual plants harvested from the landscape in June 2006.

Statistical analyses. Plants were transplanted in a completely randomized design in the landscape. All statistical analyses were performed using Statistica ${ }^{\circledR}$ software (Statsoft, Inc., Tulsa, OK). Data were tested for homogeneity of variance using Levene's test and for normality using the KolmogorovSmirnov test. Allocation data were arcsintransformed before analyses and presented as back-transformed means. Differences among irrigation treatments within a cultivar in growth, biomass allocation, and nutrient uptake were assessed using separate slopes analysis of covariance (ANCOVA) in a complete factorial design with irrigation frequency as a main effect and $2005 \mathrm{~N}$ status (mean $\mathrm{N}$ accumulation in 2005 for each cultivar $\times$ irrigation treatment $\times \mathrm{N}$ application rate; Scagel et al., 2011) as a covariate. Based on significant ANCOVA results $(P \leq 0.05)$, adjusted means $(X)$ are presented for each cultivar and irrigation treatment and regression coefficients $(\beta)$ are presented for relationships between $2005 \mathrm{~N}$ uptake and response variables. Adjusted treatment means from ANCOVA were compared using Tukey's honestly significant difference test at $P \leq$ $0.05\left(\mathrm{HSD}_{0.05}\right)$. In all regression analyses, the influence of irrigation frequency on relationships between predictor and response variables was assessed using best subsets regression with Mallow's $C P$ technique as the criterion for choosing the best subset of predictor effects from linear and quadratic models (Mallows, 1973). Differences in $\beta$ between irrigation treatments were compared using Z-tests (Paternoster et al., 1998). Flowering data were analyzed by cultivar using the Kruskal-Wallis analysis of variance and median test and means were separated at $P \leq$ 0.05 (Kruskal-Wallis ${ }_{0.05}$ ). Relationships between $2005 \mathrm{~N}$ uptake and flowering variables were assessed using Spearman rank order correlation $(R)$ at $P \leq 0.05$.

\section{Results}

Plant growth and biomass allocation. The effects of irrigation frequency during container production on the final plant size after 3 months in the landscape differed among cultivars (Table 1). More frequent irrigation (W50) increased total plant biomass and new growth in the evergreen cultivars, ER and PJM, but resulted in less biomass and growth in the deciduous cultivar, AZ. More frequent irrigation also increased the relative amount of biomass allocated to leaves in ER and stems in PJM but decreased the amount of biomass allocated to roots and new stems in ER and leaves in PJM (Table 1). Irrigation frequency had no influence on biomass allocation in AZ.

In each cultivar, new plant growth in the landscape was positively correlated to total $\mathrm{N}$ content (net $2005 \mathrm{~N}$ uptake) of the plants before transplanting (Table 1). Each cultivar also allocated more biomass to stems and less to roots when plants contained more $\mathrm{N}$ in 2005 , but only the evergreen cultivars allocated more biomass to leaves with more N, whereas the deciduous cultivar allocated less biomass to leaves (Table 1).

Flowering. More frequent irrigation during container production promoted earlier flowering, a greater percentage of plants with flowers, and more flowers per plant in the landscape in the deciduous cultivar, AZ (Table 2). It also promoted earlier flowering (in ER only) and more flowers per inflorescence 
Table 1. Plant growth and allocation of biomass in one deciduous Rhododendron cultivar, Gibraltar (AZ), and two evergreen cultivars, English Roseum (ER) and P.J.M. (PJM). ${ }^{\mathrm{z}}$

\begin{tabular}{|c|c|c|c|c|c|c|}
\hline \multirow[b]{3}{*}{ Response variables ${ }^{y}$} & \multicolumn{6}{|c|}{$X$ and $\beta_{N U 05}$ by cultivar and irrigation treatment ${ }^{\mathrm{x}}$} \\
\hline & \multicolumn{2}{|c|}{$\mathrm{AZ}$} & \multicolumn{2}{|c|}{ ER } & \multicolumn{2}{|c|}{$\begin{array}{c}\mathrm{PJM} \\
\end{array}$} \\
\hline & W100 & $\overline{\mathrm{W} 50}$ & W100 & W50 & W100 & W50 \\
\hline \multicolumn{7}{|l|}{ Total DW } \\
\hline g per plant & $32 \mathrm{~b}$ & $23 \mathrm{a}$ & $83 \mathrm{a}$ & $88 \mathrm{~b}$ & $58 \mathrm{a}$ & $63 \mathrm{~b}$ \\
\hline g per g N & $95 \mathrm{~b}$ & $66 \mathrm{a}$ & $124 \mathrm{a}$ & $184 \mathrm{~b}$ & $132 \mathrm{a}$ & $186 \mathrm{~b}$ \\
\hline \multicolumn{7}{|l|}{ Net growth after transplanting } \\
\hline $\mathrm{g}$ per plant & $12 \mathrm{~b}$ & $6 \mathrm{a}$ & $37 \mathrm{a}$ & $46 \mathrm{~b}$ & $32 \mathrm{a}$ & $39 \mathrm{~b}$ \\
\hline $\mathrm{g}$ per g N & $35 \mathrm{~b}$ & $2 \mathrm{a}$ & $57 \mathrm{a}$ & $93 \mathrm{~b}$ & $81 \mathrm{a}$ & $122 \mathrm{~b}$ \\
\hline \multicolumn{7}{|l|}{ Biomass allocation } \\
\hline \multicolumn{7}{|l|}{ Roots } \\
\hline Percent total plant & $49 \mathrm{a}$ & $48 \mathrm{a}$ & $35 \mathrm{~b}^{05}$ & $31 \mathrm{a}$ & $33 a^{05}$ & $34 \mathrm{a}$ \\
\hline Percent total plant per $\mathrm{g} \mathrm{N}$ & $-3 \mathrm{a}$ & $-4 \mathrm{a}$ & $-1 \mathrm{~b}$ & $-4 a$ & $-3 \mathrm{a}$ & $-3 \mathrm{a}$ \\
\hline \multicolumn{7}{|l|}{ All stems } \\
\hline Percent total plant & $28 \mathrm{a}^{05}$ & $29 \mathrm{a}$ & $21 \mathrm{a}$ & $20 a^{05}$ & $28 \mathrm{a}$ & $33 \mathrm{~b}$ \\
\hline Percent total plant per g N & $3 \mathrm{a}$ & $5 \mathrm{a}$ & $1 \mathrm{a}$ & $3 \mathrm{~b}$ & $2 \mathrm{a}$ & $1 \mathrm{a}$ \\
\hline \multicolumn{7}{|l|}{ New stems } \\
\hline Percent all stems & $24 \mathrm{a}$ & $26 \mathrm{a}$ & $25 \mathrm{~b}$ & $21 \mathrm{a}$ & $30 \mathrm{a}$ & $28 \mathrm{a}$ \\
\hline Percent all stems per g N & $2.1 \mathrm{~b}$ & $0.2 \mathrm{a}$ & $2.1 \mathrm{a}$ & $4.2 \mathrm{~b}$ & $0.8 \mathrm{a}$ & $0.2 \mathrm{a}$ \\
\hline \multicolumn{7}{|l|}{ All leaves } \\
\hline Percent total plant & $22 \mathrm{a}$ & $22 \mathrm{a}^{05}$ & $45 \mathrm{a}$ & $49 \mathrm{~b}$ & $39 \mathrm{~b}$ & $33 \mathrm{a}^{05}$ \\
\hline Percent total plant per $\mathrm{g} \mathrm{N}$ & $-1 \mathrm{a}$ & $-1 \mathrm{a}$ & $1 \mathrm{a}$ & $2 \mathrm{a}$ & $1 \mathrm{a}$ & $1 \mathrm{a}$ \\
\hline \multicolumn{7}{|l|}{ New leaves } \\
\hline Percent all leaves & - & - & $36 \mathrm{a}$ & $38 \mathrm{a}$ & $73 \mathrm{~b}$ & $68 \mathrm{a}^{05}$ \\
\hline Percent all leaves per g N & - & - & $0.2 \mathrm{a}$ & $0.9 \mathrm{a}$ & $-0.7 \mathrm{~b}$ & $-2.1 \mathrm{a}$ \\
\hline
\end{tabular}

${ }^{2}$ Plants were grown in containers in 2005, transplanted into the landscape in Mar. 2006, and destructively harvested in June 2006. Irrigation was applied either once (W100) or twice (W50) a day while plants were in containers using the same amount of water in both treatments each day.

yTotal DW: dry weight of all roots, stems, and leaves combined in June 2006. New growth after transplanting: change in total DW between Nov. 2005 and June 2006. Biomass allocation: percentage of total DW in structures within a plant (roots, all stems, and all leaves) and percentage of structure DW produced in 2006 (new stems, new leaves). Parameters are means $(X)$ for biomass and allocation $(\mathrm{n}=20)$ and regression coefficients for relationships between plant nitrogen $(\mathrm{N})$ status before transplanting and response variables $\left(\beta_{N U O 5}\right)$. Allocation data were arcsin-transformed before analyses and back-transformed means are presented.

${ }^{\mathrm{x}}$ Significant differences $(P \leq 0.05)$ in $X$ and $\beta_{N U 05}$ between irrigation treatments within cultivars denoted by different lower case letters within a row and cultivar. Superscript indicates significantly greater in 2005 $\left({ }^{05}\right)$ compared with other irrigation treatment within a cultivar (Scagel et al., 2011, 2012).

Table 2. Flowering responses in one deciduous Rhododendron cultivar, Gibraltar (AZ), and two evergreen cultivars, English Roseum (ER) and P.J.M. (PJM). ${ }^{\mathrm{Z}}$

\begin{tabular}{|c|c|c|c|c|c|c|}
\hline \multirow{3}{*}{$\begin{array}{l}\text { Response variables } \\
\text { and parameters }\end{array}$} & \multicolumn{6}{|c|}{$X$ and $R_{N U 05}$ by cultivar and irrigation treatment ${ }^{\mathrm{x}}$} \\
\hline & \multicolumn{2}{|c|}{$\mathrm{AZ}$} & \multicolumn{2}{|c|}{ ER } & \multicolumn{2}{|c|}{ PJM } \\
\hline & W100 & W50 & W100 & W50 & W100 & W50 \\
\hline \multicolumn{7}{|c|}{ Time of flowering (date in 2006) } \\
\hline$X$ & 8 May b & 2 May a & 10 May b & 2 May a & 10 Mar. a & 8 Mar. a \\
\hline$R_{N U 05}$ & NS & -0.463 & NS & -0.721 & NS & -0.554 \\
\hline \multicolumn{7}{|c|}{ Flowering (percent of plants) } \\
\hline$X$ & $50 \mathrm{a}$ & $65 \mathrm{~b}$ & $70 \mathrm{~b}$ & $60 \mathrm{a}$ & $85 \mathrm{~b}$ & $60 \mathrm{a}$ \\
\hline$R_{N U 05}$ & NS & NS & NS & 0.456 & NS & 0.456 \\
\hline \multicolumn{7}{|c|}{ Inflorescences (no. per plant) } \\
\hline$X$ & $2 \mathrm{a}$ & $2 \mathrm{a}$ & $13 \mathrm{~b}$ & $2 \mathrm{a}$ & $12 \mathrm{~b}$ & $1 \mathrm{a}$ \\
\hline$R_{N U 05}$ & NS & 0.819 & NS & 0.680 & NS & 0.466 \\
\hline \multicolumn{7}{|c|}{ Flowers (no. per plant) } \\
\hline$X$ & $10 \mathrm{a}$ & $17 \mathrm{~b}$ & $35 \mathrm{~b}$ & $19 \mathrm{a}$ & $33 \mathrm{~b}$ & $11 \mathrm{a}$ \\
\hline$R_{N U 05}$ & NS & 0.920 & NS & 0.824 & NS & 0.790 \\
\hline \multicolumn{7}{|c|}{ Inflorescence size (flowers per inflorescence) } \\
\hline$X$ & $7 \mathrm{a}$ & $6 \mathrm{a}$ & $3 \mathrm{a}$ & $8 \mathrm{~b}$ & 3 a & $10 \mathrm{~b}$ \\
\hline$R_{N U 05}$ & NS & 0.848 & NS & 0.794 & NS & 0.834 \\
\hline
\end{tabular}

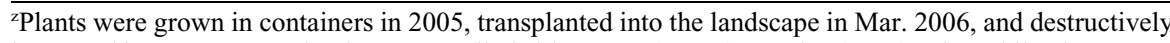
harvested in June 2006. Irrigation was applied either once (W100) or twice (W50) a day while plants were in containers using the same amount of water in both treatments each day.

'Flowering: proportion of plants with flowers by 1 June 2006. Time of flowering: date in May when first flower is fully expanded. Flowers and inflorescences: total number of flower and inflorescences produced per plant in 2006. Inflorescence size: average number of flowers in each inflorescence. Parameters are arithmetic means $(X)(\mathrm{n}=20)$ and Spearman rank order correlation $\left(R_{N U 05}\right)$ from relationships between 2005 nitrogen $(\mathrm{N})$ uptake and response variables.

${ }^{\text {x}}$ Significant differences $(P \leq 0.05$; Kruskal-Wallis analysis of variance and media test) in $X$ between irrigation treatments within cultivars denoted by different lower case letters within a row and cultivar. Significant $(P \leq 0.05)$ relationships between $2005 \mathrm{~N}$ uptake and response variable denoted by $R_{N U 05}$ values and non-significant relationships denoted by ns. in the evergreen cultivars but reduced the percentage of plants with flowers as well as the average number of inflorescences and flowers on each plant in both cultivars. When the plants were irrigated only once a day in the containers, there was no correlation between their total $\mathrm{N}$ content before transplanting and flowering in the landscape (Table 2). However, when the plants were irrigated twice a day, flowering was earlier and more abundant with increasing amounts of $\mathrm{N}$ in each cultivar.

Nutrient uptake. The effects of irrigation frequency on nutrient uptake differed among cultivars (Table 3 ). More frequent irrigation 1) decreased total nutrient uptake in AZ;2) increased total uptake of $\mathrm{N}, \mathrm{K}, \mathrm{Ca}$, and $\mathrm{Mg}$ [as well as $2006 \mathrm{P}$, sulfur (S), and B uptake] and reduced total uptake of $\mathrm{Fe}, \mathrm{Mn}, \mathrm{Cu}$, and $\mathrm{Zn}$ in ER; and (3) increased total uptake of $\mathrm{N}$, $\mathrm{Ca}, \mathrm{Mg}, \mathrm{Fe}$, and $\mathrm{Zn}$ (as well as $2006 \mathrm{P}, \mathrm{S}, \mathrm{Mn}$, and $\mathrm{B}$ uptake) and reduced uptake of $\mathrm{Cu}$ in PJM. When irrigation frequency had opposite effects on 2005 and 2006 uptake in evergreen cultivars, there was no influence of irrigation frequency on total uptake of these nutrients (e.g., P, S, and B in ER; N, P, S, Mn, and B in PJM).

Uptake of each element was positively correlated with total plant $\mathrm{N}$ content before transplanting in each cultivar (Table 4). The relationship was stronger with less frequent irrigation in AZ. In AZ, $N$ content had more influence on total uptake of nutrients and uptake in the landscape when plants were irrigated once a day in the containers rather than twice a day. In contrast, when evergreen cultivars were irrigated less frequently, plants with a similar amount of $\mathrm{N}$ before transplanting accumulated less $\mathrm{N}, \mathrm{K}, \mathrm{S}, \mathrm{Ca}, \mathrm{Mg}$, $\mathrm{Mn}$, and $\mathrm{B}$ after transplanting. The relationship between plant $\mathrm{N}$ content before transplanting and $\mathrm{Fe}$ uptake in the landscape differed markedly between the evergreen cultivars.

\section{Discussion}

Plant growth and biomass allocation. Increasing the frequency of irrigation from once a day to twice a day had no effect on plant biomass in Rhododendron while the plants were still in containers (Scagel et al., 2011), but it had a marked effect on growth the next spring after the plants were transplanted into the landscape. More frequent irrigation in containers reduced growth in the landscape in the deciduous cultivar and increased growth in the two evergreen cultivars. Increasing irrigation frequency in containers decreased water stress in containers (Scagel et al., 2011) and altered nutrient uptake in containers (Scagel et al., 2012). The effects of irrigation frequency in containers on growth in the landscape may be related to nutrient uptake in containers.

Our results indicated that growth after transplanting was not solely a function of plant size the previous fall and may be related to how irrigation frequency in containers affects other qualities in plants (e.g., nutrient 
Table 3. Nutrient uptake in one deciduous Rhododendron cultivar, Gibraltar (AZ), and two evergreen cultivars, English Roseum (ER) and P.J.M. (PJM). ${ }^{\mathrm{z}}$

\begin{tabular}{|c|c|c|c|c|c|c|}
\hline \multirow[b]{3}{*}{ Nutrient $^{\mathrm{y}}$} & \multicolumn{6}{|c|}{$X$ by cultivar and irrigation treatment ${ }^{\mathrm{x}}$} \\
\hline & \multicolumn{2}{|c|}{$\mathrm{AZ}$} & \multicolumn{2}{|c|}{ ER } & \multicolumn{2}{|c|}{ PJM } \\
\hline & W100 & $\overline{W 50}$ & W100 & W50 & W100 & W50 \\
\hline Nitrogen (mg/plant) & $293 b^{05,06}$ & $236 a$ & $636 a^{05}$ & $743 b^{06}$ & $496 \mathrm{a}^{05}$ & $545 b^{06}$ \\
\hline Phosphorus (mg/plant) & $36 b^{05,06}$ & $27 \mathrm{a}$ & $61 a^{05}$ & $66 \mathrm{a}^{06}$ & $41 \mathrm{a}^{05}$ & $42 \mathrm{a}^{06}$ \\
\hline Potassium (mg/plant) & $129 b^{06}$ & $100 \mathrm{a}$ & $378 a^{05}$ & $445 b^{06}$ & $236 \mathrm{a}$ & $246 \mathrm{a}$ \\
\hline Sulfur (mg/plant) & $20 b^{06}$ & $16 \mathrm{a}$ & $45 \mathrm{a}^{05}$ & $46 \mathrm{a}^{06}$ & $39 a^{05}$ & $38 \mathrm{a}^{06}$ \\
\hline Calcium (mg/plant) & $86 b^{06}$ & $64 \mathrm{a}$ & $346 \mathrm{a}$ & $382 b^{05,06}$ & $324 \mathrm{a}$ & $372 b^{05,06}$ \\
\hline Magnesium (mg/plant) & $62 b^{06}$ & $48 \mathrm{a}$ & $138 \mathrm{a}$ & $162 b^{06}$ & $113 \mathrm{a}$ & $125 b^{06}$ \\
\hline Iron (mg/plant) & $7.3 b^{05,06}$ & $4.2 \mathrm{a}$ & $10.1 b^{06}$ & $7.5 \mathrm{a}$ & $10.6 \mathrm{a}$ & $12.3 \mathrm{~b}^{06}$ \\
\hline Manganese (mg/plant) & $8.9 b^{05,06}$ & $6.1 \mathrm{a}$ & $23.2 b^{05,06}$ & $19.5 \mathrm{a}$ & $15.7 \mathrm{a}^{05}$ & $16.4 \mathrm{a}^{06}$ \\
\hline Boron ( $\mu \mathrm{g} /$ plant $)$ & $295 b^{05,06}$ & $229 \mathrm{a}$ & $976 \mathrm{a}^{05}$ & $1056 \mathrm{a}^{06}$ & $734 \mathrm{a}^{05}$ & $806 \mathrm{a}^{06}$ \\
\hline Copper ( $\mu \mathrm{g} /$ plant $)$ & $286 b^{05,06}$ & $172 \mathrm{a}$ & $482 b^{05,06}$ & $381 \mathrm{a}$ & $507 b^{06}$ & $428 \mathrm{a}$ \\
\hline Zinc $(\mu \mathrm{g} /$ plant $)$ & $889 b^{05,06}$ & $594 \mathrm{a}$ & $2116 b^{05,06}$ & $1875 \mathrm{a}$ & $1595 \mathrm{a}$ & $1842 b^{06}$ \\
\hline
\end{tabular}

zPlants were grown in containers in 2005, transplanted into the landscape in Mar. 2006, and destructively harvested in June 2006. Irrigation was applied either once (W100) or twice (W50) a day while plants were in containers using the same amount of water in both treatments each day.

y Parameters are means $(X)$ for total plant nutrient content $(\mathrm{n}=20)$.

xignificant differences $(P \leq 0.05)$ in $X$ and $\beta_{N U 05}$ between irrigation treatments within cultivars denoted by different lower case letters within a row and cultivar. Superscript indicates significantly greater in 2005 $\left({ }^{05}\right)$ or $2006\left({ }^{06}\right)$ compared with other irrigation treatment within a cultivar (Scagel et al., 2011, 2012)

Table 4. Relationship between plant nitrogen $(\mathrm{N})$ status before transplanting and net nutrient uptake in one deciduous Rhododendron cultivar, Gibraltar (AZ), and two evergreen cultivars, English Roseum (ER) and P.J.M. (PJM). ${ }^{\mathrm{z}}$

\begin{tabular}{|c|c|c|c|c|c|c|}
\hline \multirow[b]{3}{*}{ Nutrient ${ }^{\mathrm{y}}$} & \multicolumn{6}{|c|}{$\beta_{N U 05}$ by cultivar and irrigation treatment ${ }^{x}$} \\
\hline & \multicolumn{2}{|c|}{ AZ } & \multicolumn{2}{|c|}{ ER } & \multicolumn{2}{|c|}{ PJM } \\
\hline & W100 & W50 & W100 & W50 & $\overline{\mathrm{W} 100}$ & W50 \\
\hline Nitrogen (mg per g N) & $1183 b^{06}$ & $762 \mathrm{a}$ & $1074 \mathrm{a}$ & $1635 \mathrm{~b}^{06}$ & $1237 \mathrm{a}$ & $1612 b^{06}$ \\
\hline Phosphorus (mg per g N) & $124 b^{06}$ & $74 \mathrm{a}^{05}$ & $93 \mathrm{a}$ & $121 \mathrm{~b}$ & $98 \mathrm{a}$ & $117 \mathrm{a}$ \\
\hline Potassium (mg per $\mathrm{g} \mathrm{N}$ ) & $360 b^{06}$ & $237 \mathrm{a}^{05}$ & $413 \mathrm{a}$ & $749 b^{05,06}$ & $394 \mathrm{a}$ & $550 b^{05}$ \\
\hline Sulfur (mg per g N) & $69 b^{06}$ & $47 \mathrm{a}^{05}$ & $87 \mathrm{a}$ & $103 b^{06}$ & $96 \mathrm{a}$ & $119 b^{06}$ \\
\hline Calcium (mg per $\mathrm{g} \mathrm{N}$ ) & $322 b^{06}$ & $159 \mathrm{a}^{05}$ & $621 \mathrm{a}$ & $857 b^{05,06}$ & $961 \mathrm{a}$ & $1276 b^{05,06}$ \\
\hline Magnesium (mg per g N) & $207 b^{06}$ & $121 \mathrm{a}^{05}$ & $231 \mathrm{a}$ & $334 b^{05,06}$ & $307 \mathrm{a}$ & $388 b^{05,06}$ \\
\hline Iron (mg per $\mathrm{g} \mathrm{N})$ & $31 b^{06}$ & $7 \mathrm{a}$ & $20 b^{05,06}$ & $12 \mathrm{a}$ & $18 \mathrm{a}$ & $37 b^{05,06}$ \\
\hline Manganese (mg per g N) & $14 b^{06}$ & $5 \mathrm{a}^{05}$ & $8 \mathrm{a}$ & $24 b^{05,06}$ & $20 \mathrm{a}$ & $30 b^{05}$ \\
\hline Boron $(\mu \mathrm{g}$ per $\mathrm{g} \mathrm{N})$ & $0.98 b^{06}$ & $0.56 \mathrm{a}$ & $0.88 \mathrm{a}$ & $1.51 \mathrm{~b}^{06}$ & $1.18 \mathrm{a}$ & $1.87 b^{05,06}$ \\
\hline Copper $(\mu \mathrm{g}$ per $g \mathrm{~N})$ & $1.01 \mathrm{~b}^{06}$ & $0.30 \mathrm{a}$ & $0.70 \mathrm{a}$ & $0.52 \mathrm{a}$ & $0.87 \mathrm{a}$ & $1.07 \mathrm{a}^{05}$ \\
\hline $\operatorname{Zinc}(\mu \mathrm{g}$ per $\mathrm{g} \mathrm{N})$ & $2.9 \mathrm{~b}^{06}$ & $1.3 \mathrm{a}$ & $3.5 \mathrm{a}$ & $3.3 \mathrm{a}$ & $3.7 \mathrm{a}$ & $5.1 \mathrm{a}$ \\
\hline
\end{tabular}

zPlants were grown in containers in 2005, transplanted into the landscape in Mar. 2006, and destructively harvested in June 2006. Irrigation was applied either once (W100) or twice (W50) a day while plants were in containers using the same amount of water in both treatments each day.

y Parameters are regression coefficients for relationships between plant $\mathrm{N}$ status before transplanting and response variables $\left(\beta_{N U 05}\right)$.

${ }^{x}$ Significant differences $(P \leq 0.05)$ in $\beta_{N U 05}$ between irrigation treatments within cultivars denoted by different lower case letters within a row and cultivar. Superscript indicates significantly greater in $2005\left({ }^{05}\right)$ or $2006\left({ }^{06}\right)$ compared with other irrigation treatment within a cultivar (Scagel et al., 2011, 2012).

uptake and use, biomass allocation, and carbohydrate reserves) (Scagel et al., 2011). Growth after transplanting is an important quality characteristic for nursery stock. There are reports of positive, negative, and no relationship between initial plant size and subsequent performance in the landscape; other factors such as plant form and composition may play a stronger role than plant size in predicting post-transplant success (Folk and Grossnickle, 1997; Miguel et al., 2010; Wright et al., 2007).

Less frequent irrigation in containers caused transient increases in water stress in AZ (Scagel et al., 2011), which may explain why the plants irrigated once a day had earlier spring growth in the landscape than those irrigated twice a day. Conversely, more frequent irrigation could have decreased growth in AZ because it delayed nutrient mobilization to storage. Low levels of water stress in containers can promote early nutrient mobilization in the fall and spring (Sanz-Pérez et al., 2009). Delayed nutrient mobilization could also reduce cold-hardiness and result in tissue damage and loss of biomass over the winter (Colombo et al., 2003; Scagel et al., 2010).

For all cultivars, more frequent irrigation generally decreased uptake of several nutrients in containers (Scagel et al., 2011, 2012), and this could account for less growth of the deciduous cultivar in the landscape. However, the same relationship between nutrient uptake in containers and growth in the landscape was not found in evergreen cultivars, indicating enhanced growth of evergreen cultivars in the landscape was not a direct result of improved nutrient uptake in containers. In each cultivar, growth was greater in the landscape when the plants acquired more $\mathrm{N}$ while in the containers. However, the plants from the deciduous cultivar used the $\mathrm{N}$ less efficiently (grams dry weight per unit N) in the landscape when irrigated twice a day in containers than only once a day; the opposite effect occurred in evergreen cultivars. This suggests that more frequent irrigation reduces the ability of deciduous cultivars such as AZ to use $\mathrm{N}$ reserves for new growth and increases that ability of evergreen cultivars such as ER and PJM.

There is a strong link between nutrient reserves and growth in woody perennials, but nutrients absorbed early in the growing season are stored and mobilized differently than nutrients absorbed later in the growing season (Dong et al., 2005; Millard and Grelet, 2010). The majority of nutrient uptake by container-grown deciduous Rhododendron cultivars occurs earlier in the growing season than nutrient uptake by evergreen cultivars (Bi et al., 2007b; Scagel et al., 2007, 2008). More frequent irrigation in containers can decrease early-season nutrient availability in containers or the ability of plants to accumulate nutrients early in the growing season (Scagel et al., 2011, 2012). Differences in growth responses to irrigation frequency between $A Z$ and the evergreen cultivars may be related to when the cultivars absorbed nutrients and whether nutrients absorbed early in the growing season are stored and mobilized differently than nutrients absorbed later in the season.

Irrigation frequency in containers altered vegetative biomass allocation of evergreen Rhododendron cultivars after transplanting in the landscape. Biomass allocation above ground after transplanting can potentially influence aspects of plant form important to perceived quality by consumers (Miguel et al., 2010). Less frequent irrigation in containers resulted in more open or sparser plants (i.e., fewer leaves with a similar proportion of stems) in ER and more compact or full plants (i.e., more leaves with fewer stems) in PJM.

Flowering. Irrigation frequency in containers differentially influenced reproductive performance in the landscape in all three cultivars. In the deciduous cultivar, AZ, less frequent irrigation in containers increased vegetative growth and decreased flower production in the landscape, whereas in the evergreen cultivars, ER and PJM, it decreased vegetative growth and generally increased flower production. These results suggest that irrigation frequency (and greater water stress) in containers results in a tradeoff between vegetative and reproductive growth in Rhododendron the next spring.

Irrigation frequency in containers altered if and when Rhododendron flowered after transplanting in the landscape. Plants that flower after transplanting or flower earlier are sometimes considered to be of higher quality by growers and consumers. Floral initiation can be inhibited by water deficits in Rhododendron (Sharp et al., 2008), whereas earlier flowering can be promoted (Cameron et al., 1999; Dickey et al., 1963; Sharp et al., 2008). Earlier flowering is generally not a result of increased floral initiation. If water stress 
occurs before the time of initiation, fewer vegetative nodes are formed before floral initiation, and floral initiation occurs earlier and may be decreased (Sharp et al., 2008). Continued water deficits may also reduce the chilling requirement necessary to induce anthesis and promote early flowering (Criley, 1985). Our results indicate that less frequent irrigation in containers may increase the potential for spring flowering in evergreen cultivars of Rhododendron but may delay the timing of flowering in both evergreen (ER) and deciduous (AZ) cultivars.

Some woody ornamental species initiate more flowers under water stress as a result of resource mobilization for reproductive development (Sharp et al., 2008). However, Sharp et al. (2008) indicated that this strategy did not appear to evolve in Rhododendron. Instead Rhododendron are thought to respond to water deficits by initiating flowers earlier and maintaining reproductive capacity at the expense of vegetative growth (Sharp et al., 2008). This theory is not totally supported in the cultivars used in our study. A mild level of water stress imposed by less frequent irrigation (Scagel et al., 2011) did not promote early flowering in any cultivar; however, the evergreen cultivars responded to water deficits by maintaining reproductive capacity at the expense of vegetative growth. Our results may have varied from those of Sharp et al. (2008) because the $\mathrm{N}$ rates we applied increased plant water stress in containers (Scagel et al., 2011) and greater plant $\mathrm{N}$ status decreased the tradeoff between reproductive and vegetative growth in the spring.

In the evergreen cultivars, less frequent irrigation generally increased the number of flowers and inflorescences and decreased inflorescence size and plant growth. These results suggest that smaller inflorescences may be related to water stress (e.g., less frequent irrigation) during floral initiation in the containers. Deficit irrigation has been reported to improve flowering and growth characteristics of container-grown Rhododendron (Cameron et al., 1999; Koniarski and Matysiak, 2013; Sharp et al., 2008). Water stress from deficit irrigation can stimulate the development of more flowers on each inflorescence in Rhododendron when the practices occur after plants have undergone floral initiation (Koniarski and Matysiak, 2013; Sharp et al., 2008). Our results indicated that transient water stress during container production can decrease inflorescence size in evergreen cultivars, but plants produced more inflorescences and flowers when they are transplanted the next spring, resulting in plants that may be considered higher quality (more compact and floriferous).

Nutrient uptake. The effects of irrigation frequency on nutrient uptake differed among cultivars and among nutrients in both containers (2005) and in the landscape (2006). Less nutrient uptake in containers coincided with less growth in the landscape in the deciduous cultivar (AZ) and greater growth in the evergreen cultivars (ER and PJM).
Nitrogen reserves play a major role in driving plant growth and associated demand and uptake for other nutrients. There are many reports of positive relationships between $\mathrm{N}$ reserves and spring growth (Cabrera and Devereaux, 1999; Close et al., 2004; Millard and Grelet, 2010). In our study, greater plant $\mathrm{N}$ status before transplanting was positively correlated with total nutrient uptake in each cultivar; however, the magnitude of these relationships differed among the cultivars and between irrigation treatments. Although plant $\mathrm{N}$ status was related to nutrient uptake or demand the next spring, irrigation frequency in containers disrupted the relationship between plant $\mathrm{N}$ status and uptake for several nutrients.

Overall, more frequent irrigation of $\mathrm{AZ}$ in containers decreased nutrient uptake in containers (Scagel et al., 2012), decreased nutrient uptake in the landscape, and increased the plant demand for all nutrients in the landscape except $\mathrm{Ca}$. These results further support the theory that reduced growth with more frequent irrigation in $\mathrm{AZ}$ may be related to how irrigation frequency influenced nutrient reserves.

In evergreen cultivars, more frequent irrigation decreased total $\mathrm{Mn}, \mathrm{Cu}$, and $\mathrm{Zn}$ uptake in ER and total S uptake in PJM, primarily through its influence on nutrient uptake in containers. These results suggest that the effects of irrigation frequency on uptake of these nutrients in containers did not restrict ER and PJM performance in terms of growth but may have decreased demand or ability of plants to absorb these nutrients in the landscape. The effects of irrigation frequency on uptake of these nutrients in the landscape may not impact growth until later in the growing season. Similarly, more frequent irrigation decreased total Fe uptake in $\mathrm{ER}$ and total $\mathrm{Cu}$ uptake in PJM through its influence on 2006 uptake. These results suggest that lower $\mathrm{Fe}$ and $\mathrm{Cu}$ uptake in the landscape did not alter growth early in the growing season but may affect it later in the season.

Plant $\mathrm{N}$ status in containers appears to play a role in nutrient uptake and demand by Rhododendron in the landscape, and irrigation frequency can alter the relationships between nutrient reserves and growth the next spring. In an unfertilized landscape, where nutrient availability will be lower than in containers, growth would primarily depend on plant reserves until a balance between nutrients is attained within the plant as it adjusts to the new growing environment (Chapin et al., 1987). Our results indicate that less frequent irrigation in containers may have improved how efficiently the deciduous cultivar uses reserves for growth and uptake in the landscape but decreased how efficiently the evergreen cultivars used their reserves. In crape myrtle (Lagerstroemia indica), the rate of $\mathrm{N}$ fertilizer application altered plant uptake of $\mathrm{N}, \mathrm{Ca}, \mathrm{S}$, and $\mathrm{Fe}$ in containers but had little effect on the concentrations of the nutrients by 16 weeks after transplanting into a landscape (Cabrera and Devereaux, 1999). In our study, it is possible that the effects of irrigation and $\mathrm{N}$ rate on nutrient uptake in Rhododendron may have been less evident in the landscape as the growing season continued.

Transplanting performance depends on plant morphological and physiological attributes, which can be determined to a great extent by cultivation practices in the nursery (Cuesta et al., 2010; Van den Driessch, 1991; Villar-Salvador et al., 2004). Some studies report positive correlations between transplanting performance and plant $\mathrm{N}$ concentration (Van den Driessch, 1991; Villar-Salvador et al., 2004). In our study, the influence of irrigation frequency on relationships between nutrient reserves and plant performance in the landscape differed between the deciduous and evergreen cultivars. Our results also indicate that the influence of irrigation frequency on plant nutrient composition in containers can alter plant performance in the landscape through the relationships among nutrient reserves and growth, flowering, and the ability of plants to absorb nutrients.

Resource competition. Competition between vegetative and reproductive growth for resources from reserves and spring nutrient uptake may play a role in plant growth responses to irrigation frequency. In evergreen cultivars, more frequent irrigation promoted early flowering (ER) and decreased flower production (ER and PJM). More frequent irrigation may have increased growth because evergreen cultivars preferentially allocated available resources to vegetative growth. More frequent irrigation also decreased water stress of evergreen cultivars in containers (Scagel et al., 2011), but the negative impact of more frequent irrigation on the nutrition of evergreen cultivars in containers did not carry over to the landscape. These results indicate that increasing water availability or decreasing water stress in containers alters stock qualities, which improve early-season uptake of nutrients and vegetative growth of evergreen cultivars in the landscape (albeit at the expense of potential benefits to flowering).

In AZ, more frequent irrigation decreased uptake of several nutrients in containers (Scagel et al., 2011, 2012) and vegetative growth in the landscape, and plant $\mathrm{N}$ status before transplanting had less influence on growth and nutrient uptake in the landscape when the plants were irrigated less frequently. Although more frequent irrigation decreased water stress of AZ in containers (Scagel et al., 2011), the negative impact of more frequent irrigation on $\mathrm{AZ}$ nutrition in containers appears to have had a larger effect on vegetative growth after transplanting. Additionally, AZ plants irrigated twice a day were less able to absorb nutrients and grow after transplanting than those irrigated once a day, when the plants had a similar $\mathrm{N}$ status before transplanting. Thus, irrigation frequency in containers altered plant qualities that either decreased the ability of plants to absorb nutrients in the landscape or decreased their nutrient demands.

This study describes the effects of irrigation frequency on plants grown for only 
1 year in containers. Environmental differences between years and cultivar variations may provide different results in terms of the magnitude of nutrient uptake and the specific nutrient relationships and growth and flowering characteristics that were altered by irrigation frequency. Although extrapolation of these specific results from this study across environments and cultivars is limited, this study highlights several concepts important to understanding how nutrient and water management in container production of perennial nursery crops can alter plant performance in the landscape. Post-transplant success may be correlated with plant nutrient status at transplanting (Cabrera and Devereaux, 1999); however, interactions between nutrient and water management during container production and differences among cultivars in vegetative and reproductive development may complicate effective deployment of irrigation decision tools.

\section{Literature Cited}

Arreola, J., J.A. Franco, M.A. Vincente, and J.J. Martinez-Sanchez. 2006. Effect of nursery irrigation regimes on vegetative growth and root development of Silene vulgaris after transplantation into semi-arid conditions. J. Hort. Sci. Biotechnol. 81:583-592.

Beeson, R.C., Jr. 1992. Restricting overhead irrigation to dawn limits growth in container-grown woody ornamentals. HortScience 27:996-999.

Beeson, R.C., Jr. 2006. Relationship of plant growth and actual evapotranspiration to irrigation frequency based on management allowed deficits for container nursery stock. J. Amer. Soc. Hort. Sci. 131:140-148.

Bi, G., C.F. Scagel, L.H. Fuchigami, and R.P. Regan. 2007a. Rate of nitrogen application during the growing season alters the response of container-grown rhododendron and azalea to foliar application of urea in the autumn. J. Hort. Sci. Biotechnol. 82:753-763.

Bi, G., C.F. Scagel, L.H. Fuchigami, and R.P. Regan. 2007b. Differences in growth, and nitrogen uptake and storage between two containergrown cultivars of Rhododendron. J. Environ. Hort. 25:13-20.

Bilderback, T.E. 2002. Water management is key in reducing nutrient runoff from container nurseries. HortTechnology 12:7-9.

Cabrera, R.I. and D. Devereaux. 1999. Crape myrtle post-transplant growth as affected by nitrogen nutrition during nursery production. J. Amer. Soc. Hort. Sci. 124:94-98.

Cameron, R., R. Harrison-Murray, M. Fordham, S. Wildinson, W. Davies, C. Atkinson, and M. Else. 2008. Regulated irrigation of woody ornamentals to improve plant quality and precondition against drought stress. Ann. Appl. Biol. 153:49-61.

Cameron, R.W.F., R.S. Harrison-Murray, C.J. Atkinson, and H.L. Judd. 2006. Regulated deficit irrigation-A means to control growth in woody ornamentals. J. Hort. Sci. Biotechnol. 81:435-443.

Cameron, R.W.F., R.S. Harrison-Murray, and M.A. Scott. 1999. The use of controlled water stress to manipulate growth of container-grown
Rhododendron cv Hoppy. J. Hort. Sci. Biotechnol. 74:161-169.

Chapin, F.S., III, A.J. Bloom, C.B. Field, and R.H. Waring. 1987. Plant responses to multiple environmental factors. Bioscience 37:49-57.

Close, D.C., I. Bail, S. Hunter, and C.L. Beadle. 2004 Effects of exponential nutrient-loading on morphological and nitrogen characteristics and on after-planting performance of Eucalyptus globulus seedlings. For. Ecol. Mgt. 205:397-403.

Colombo, S.J., C.G. Lerum, and D.P. Webb. 2003. Daylength, temperature, and fertilization effects on desiccation resistance, cold hardiness, and root growth potential of Picea mariana seedlings. Ann. For. Sci. 60:307-317.

Criley, R.A. 1985. Rhododendrons and azaleas. In: Halevy, A.H. (ed.). Handbook of flowering. Vol. 4. CRC Press, Boca Raton, FL.

Cuesta, B., P. Villar-Salvador, J. Puértolas, D.F Jacobs, and J.M. Rey Benayas. 2010. Why do large, nitrogen rich seedlings better resist stressful transplanting conditions? A physiological analysis in two functionally contrasting Mediterranean forest species. For. Ecol. Mgt. 260:71-78.

Dickey, R.D., R.T. Poole, and J.N. Joiner. 1963. Effect of watering frequencies, time and rate of fertilization on growth and chemical composition of Rhododendron indicum 'Formosa' and Viburnum suspensum. Proc. Fla. Sta. Hort. Soc. 76:431-436.

Dong, S., L. Cheng, C.F. Scagel, and L.H. Fuchigami. 2005. Timing of urea application affects leaf and root $\mathrm{N}$ uptake in young Fuji/M.9 apple trees. J. Hort. Sci. Biotechnol. 80:116-120.

Fare, D.C., C.H. Gilliam, G.J. Keever, and J.W. Olive. 1994. Cyclic irrigation reduces container leachate nitrate-nitrogen concentration. HortScience 29:1514-1517.

Folk, R.S. and S.C. Grossnickle. 1997. Determining field performance potential with the use of limiting environmental conditions. New For. 13:121-138.

Franco, J.A., J.J. Martinez-Sanchez, J.A. Fernandez, and S. Banon. 2006. Selection and nursery production of ornamental plants for landscaping and xerogardening in semi-arid environments. Hort. Sci. Biotechnol. 81:3-17.

Keever, G.J. and G.S. Cobb. 1985. Irrigation scheduling effects on container media and canopy temperatures and growth of 'Hershey's red' azalea. HortScience 20:921-923.

Koniarski, M. and B. Matysiak. 2013. Growth and development of potted Rhododendron cultivars 'Catawbiense Boursault' and 'Old Port' in response to regulated deficit irrigation. J. Hort. Res. 21:29-37.

Lea-Cox, J.D., W.L. Bauerle, M.W. van Iersel, G.F. Kantor, T.L. Bauerle, E. Lichtenberg, D.M. King, and L. Crawford. 2013. Advancing wireless sensor networks for irrigation management of ornamental crops: An overview. HortTechnology 23:717-724.

Mallows, C.L. 1973. Some comments on Cp. Technometrics 15:661-675.

Miguel, C., X. Aranda, F. De Herralde, S. Sabaté, C. Biel, and R. Savé. 2010. Evaluation of growth slowdown nursery treatment of Prunus avium seedlings by means of allometric relationships and relative growth rates. Scand. J. For. Res. 25:51-59.

Millard, P. and G.-A. Grelet. 2010. Nitrogen storage and remobilization by trees: Ecophys- iological relevance in a changing world. Tree Physiol. 30:1083-1095.

Paternoster, R., R. Brame, P. Mazerolle, and A. Piquero. 1998. Using the correct statistical test for the quality of regression coefficients. Criminology 38:859-866.

Raviv, M., R. Wallach, A. Silber, S. Medina, and A. Krasnovsky. 1999. The effect of hydraulic characteristics of volcanic materials on yield of roses grown in soilless culture. J. Amer. Soc. Hort. Sci. 124:205-209.

Sánchez-Blanco, M.J., T. Ferrández, A. Navarro, S. Bañon, and J.J. Alarcón. 2004. Effects of irrigation and air humidity preconditioning on water relations, growth and survival of Rosmarinus officinalis plants during and after transplanting. J. Plant Physiol. 161:11331142.

Sanz-Pérez, V., P. Castro-Díez, and R. Joffre. 2009. Seasonal carbon storage and growth in Mediterranean tree seedlings under different water conditions. Tree Physiol. 29:11051116.

Scagel, C.F., G. Bi, L.H. Fuchigami, and R.P. Regan. 2007. Seasonal variation in growth, nitrogen uptake and allocation by containergrown evergreen and deciduous Rhododendron cultivars. HortScience 42:1440-1449.

Scagel, C.F., G. Bi, L.H. Fuchigami, and R.P. Regan. 2008. Nitrogen availability alters mineral nutrient uptake and demand in containergrown deciduous and evergreen Rhododendron. J. Environ. Hort. 26:177-187.

Scagel, C.F., G. Bi, L.H. Fuchigami, and R.P. Regan. 2011. Effects of irrigation frequency and nitrogen fertilizer rate on water stress, nitrogen uptake, and plant growth of container-grown Rhododendron. HortScience 46:1598-1603.

Scagel, C.F., G. Bi, L.H. Fuchigami, and R.P. Regan. 2012. Irrigation frequency alters nutrient uptake in container-grown Rhododendron plants grown with different rates of nitrogen. HortScience 47:189-197.

Scagel, C.F., R. Regan, R. Hummel, and G. Bi. 2010. Cold tolerance of container-grown green ash trees is influence by nitrogen fertilizer type and rate. HortTechnology 20:292303.

Sharp, R.G., M.A. Else, R.W. Cameron, and W.J. Davies. 2008. Water deficits promote flowering in Rhododendron via regulation of pre and post initiation development. Sci. Hort. 120:511517.

Van den Driessch, R. 1991. Influence of container nursery regimes on drought resistance of seedlings following planting. I. Survival and growth. Can. J. For. Res. 21:555-565.

Villar-Salvador, P., R. Planelles, E. Enríquez, and J.L. Peñuelas Rubira. 2004. Nursery cultivation regimes, plant functional attributes, and field performance relationships in the Mediterranean oak Quercus ilex L. For. Ecol. Mgt. 196:257266.

Welsh, D.F. and J.M. Zajicek. 1993. A model for irrigation scheduling in contain-grown nursery crops utilizing management allowed deficits (MAD). J. Environ. Hort. 11:115-118.

Wright, A.N., S.L. Warren, and F.A. Blazich. 2007. Effect of root-zone temperature on survival, growth, and root morphology of Kalmia latifolia and Ilex crenata 'Compacta'. J. Environ. Hort. 25:73-77. 